\title{
ON SOME CHYDORID AND MACROTHRICID (CRUSTACEA: CLADOCERA) FROM PUNJAB WITH THE DESCRIPTION OF THREE NEW SPECIES
}

With 49 Figures

\author{
By
}

\section{S. K. BAtTish}

(Department of Zoology, Punjab Agricultural University, Ludhiana, India)

$$
\begin{aligned}
& \text { パンジャブ地方 (インド) の } 3 \text { 新種を含むミジンコ類 } \\
& \text { (まるみじんこ科 けぶかみじんこ科) }
\end{aligned}
$$

\section{挿図 49}

\author{
S.K. バティシュ
}

(パンジャブ農科大学動物学教室, インド)

\begin{abstract}
Twelve species of Cladocera belonging to the families Chydoridae and Macrothricidae are discussed and illustrated from Punjab, India. The assemblage, of which three species are new includes: Alona dhilloni sp. nov., Alona pulchella KING, Biapertura sp. indet., Camptocercus kapuri sp. nov., Ledigia ciliata GAUThier, Oxyurella singalensis (DADAY), Chydorus sp. cf. ciliatus Poggenpol, Chydorus eurynotus brehmi Biswas, Chydorus parvus parvus DADAY, Dunhevedia crassa KInG, Ilyocryptus spinifer HeRRICK, aed Ilyocryptus bhardwaji sp. nov.
\end{abstract}

\section{Introduction}

Our knowledge of the cladoceran fauna of Punjab is very meagre. But for ARORA's (1931) work on the entomostracan fauna of Lahore (now in Pakistan) which included an account of thirteen cladoceran species belonging to eight genera, check-list of twentythree species by the present author (BATTISH, 1974) and a brief communication by VASISHT and BATTISH (1974) practically nothing is known of these animals from Punjab. Work on the cladoceran fauna from other parts of India is also far from satisfactory. However, the references dealing with these animals are those of BAIRD (1860), GURNEY (1906, 1907), Sewell (1934), Brehm (1936, 1950, 1952, 1953, 1963), Biswas (1964, 1966a, 1966b), Petkovski (1966), Michael (1968), Nayar (1971), TAndon and Nayyar (1971), VASISHT and SINGH (1972) and NASAR (1977). 
Repository: The type material alongwith the other collection is at present housed in the Museum of the Department of Zoology, Punjab Agricultural University, Ludhiana. However, the author intends to deposit the type specimens in the Zoological Museum of Zoological Survey of India, Calcutta subsequently.

\section{Material and Methods}

Cladoceran samples were collected from water bodies of different dimensions scattered all over Punjab. The collection sites included both stagnant and slowly moving water bodies, ranging in size from small roadside ditches having water expanse of less than a metre to the largest water bodies in Punjab and Himachal Pradesh (the neighbouring State), the largest being the Govind Sagar with an area of about $168 \mathrm{~km}^{2}$. Figure 1 gives the location of the collection sites from where the species considered in this paper were collected.

The collections were made with a tow-net of fine mesh synthetic cloth (300 meshes per sq. $\mathrm{cm}$ ). The net was thrown in the habitat from the shore and pulled slowly by its rope. The specimens were killed in $5 \%$ formalin and subsequently transferred to a mixture of $70 \%$ alcohol and glycerine in the ratio of $9: 1$ for preservation. The animals were dissected under a binocular stereo-microscope $(18 \times 8 \times)$ in a drop of

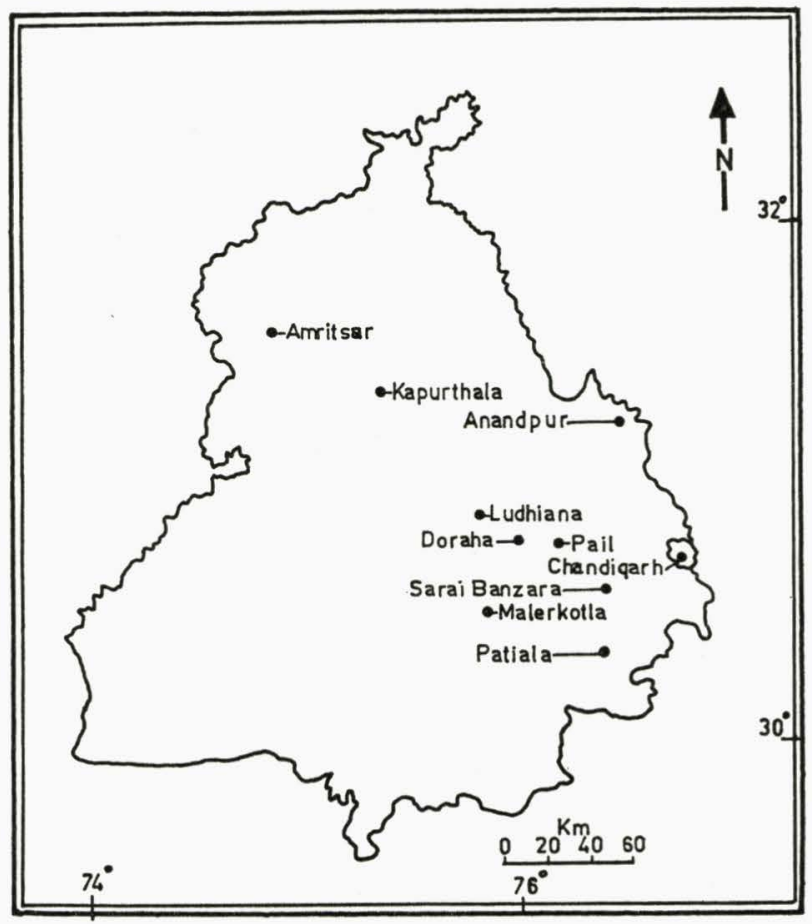

Fig. 1. Map of Punjab showing the collection sites. 
FARRANT's medium with the help of tungsten needles. Whole animals were mounted in canada balsam or D.P.X. after staining with borax carmine and dehydrating. The figures were drawn with the help of a camera lucida.

\section{Systematics}

Family Chydoridae StebBing, 1902

Subfamily Aloninae FrEY, 1967

Alona dhilloni* sp. nov.

(Figs. 2-5)

Diagnosis: Head shield continuous with valves; longitudinal lines occur on head shield and carapace, conspicuous on dorsal and dorsolateral portions of carapace, faint on lateral and ventral sides; postabdomen with nine denticles, nine groups of lateral setae and with projecting preanal corner.

Female: Dorsal surface of carapace evenly convex, ventral-edge straight, posterodorsal corner forming an angle of about $140^{\circ}$, posteroventral corner broadly rounded, maximum height of carapace posterior to the middle; twenty faint lines on lateral and ventral sides of valves, about twelve prominent dorsolateral lines extending to head shield with rounded anterior and posterior margins, head pores situated close to the posterior margin, narrowly connected; antennal spines not reaching to apex of rostrum; antennal setae $1-1-3 / 0-0-3$; plate of labrum rounded; preanal corner of postabdomen projecting, dorsal distal corner truncate, bearing about nine denticles, lateral setae occur in nine groups, ratio between distance from preanal corner to base of claws and maximum width of postabdomen, $10: 18$, claw with a basal spine, concave surface smooth; eye and ocellus of almost same size, ocellus situated near to eye than to apex of rostrum.

* This species is named in honour of Dr. S.S. Dhillon, Professor and Head, Department of Zoology, Punjabi University, Patiala.

Alona dhilloni sp. nov., female

Fig. 2. Female from left side.

Fig. 3. Head shield showing head pores.

Fig. 4. Keel of labrum.

Fig. 5. Postabdomen.

Alona pulchella King, female

Fig. 6. Entire from left side.

Fig. 7. Head pores.

Fig. 8. Antennule.

Fig. 9. Keel of labrum.

Fig. 10. Postabdomen.

Fig. 11. Part of postabdomen. 


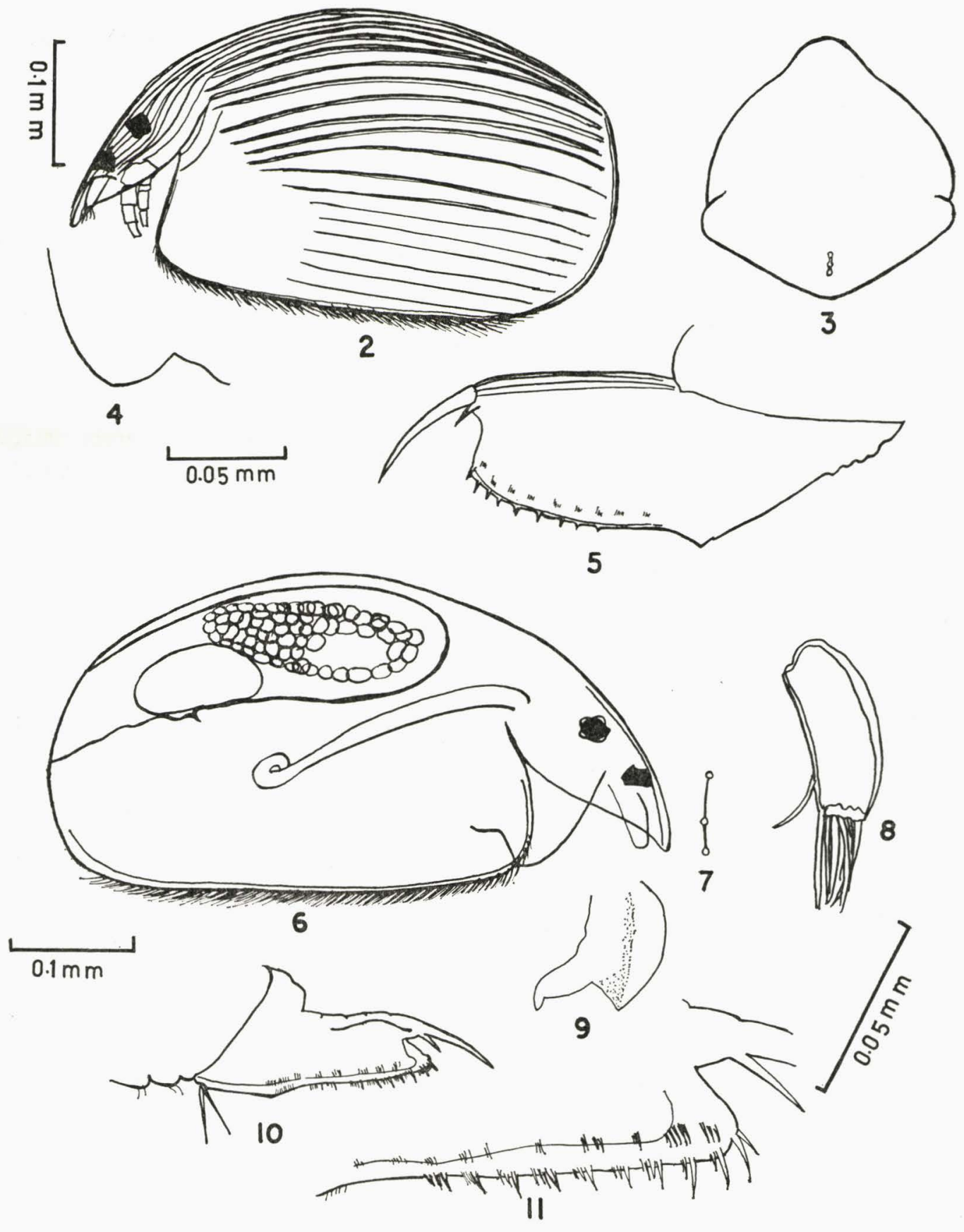


Holotype: (Slide No. $\mathrm{C}_{1 \mathrm{~F}_{1}}$ ) (우) $*$ Length $=0.46 \mathrm{~mm}$, Height $=0.29 \mathrm{~mm}$.

Paratype: (Slides No. $\mathrm{C}_{1} \mathrm{~F}_{2}$ to $\mathrm{C} 1 \mathrm{~F}_{9}, \mathrm{ClFa}, \mathrm{C} 1 \mathrm{Fb}$ ) (우 우) $*$ Length $=0.43-0.46 \mathrm{~mm}$, Height $=0.25-0.29 \mathrm{~mm}$.

Colour: Light yellow.

Male: Not found.

Type locality: Twentyone female specimens of Alona dhilloni sp. nov. were collected from a shallow pond about a half hectare in area, located near the Railway Station of Sarai Banzara (District Patiala) on 6 January, 1977. The water of the pond was acidic ( $\mathrm{pH}$ 5.5).

Remarks: Alona dhilloni sp. nov. resembles Alona bukobensis Weltner, 1896 somewhat, yet differs from it in some characters. The longitudinal lines occur in both these species but are prominent on the dorsal and dorsolateral sides in the present new species. The other differences are: Ocellus is larger than eye and situated near to it than to the tip of rostrum; dorsal distal side of the postabdomen truncated bearing nine denticles and nine groups of lateral setae; claw lacks setae on its concave margin.

Alona pulclahle KING, 1853

(Figs. 6-11)

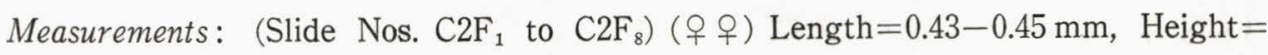
$0.26-0.29 \mathrm{~mm}$.

Locality: This species was common (more than twenty) in a collection made from a pond near Model Town, Ludhiana on 11 October, 1976, alongwith Simocephalus vetulus (Schodler), Daphnia similis Claus and Dunhevedia crass KIng. Besides Cladocera, the pond was rich in Ostracoda as well as floating vegetation. Alona pulchella was also collected on 10 January, 1977 from Punjab Agricultural University, Ludhiana Nursery tank and from a pond near Kapurthala on 7 May, 1977.

Remarks: Vasisht and Battish (1974) recorded A. pulchella from a fish tank at Chandigarh, India and it is for the first time that this species is being recorded from Ludhiana and Kapurthala, Punjab. The specimens collected from Chandigarh slightly differ from the material at hand as in the former the dorsal side of the postabdomen is more curved than that of the latter.

Diapertura sp. indet.

(Figs. 12, 13)

Female: Body subovate, valves with longitudinal lines, more prominent on the posterior half of valves, maximum height lies in the middle of body; rostrum blunt,

\footnotetext{
* The size ranges pertain only to the reproductives for all the taxa included in this paper.
} 


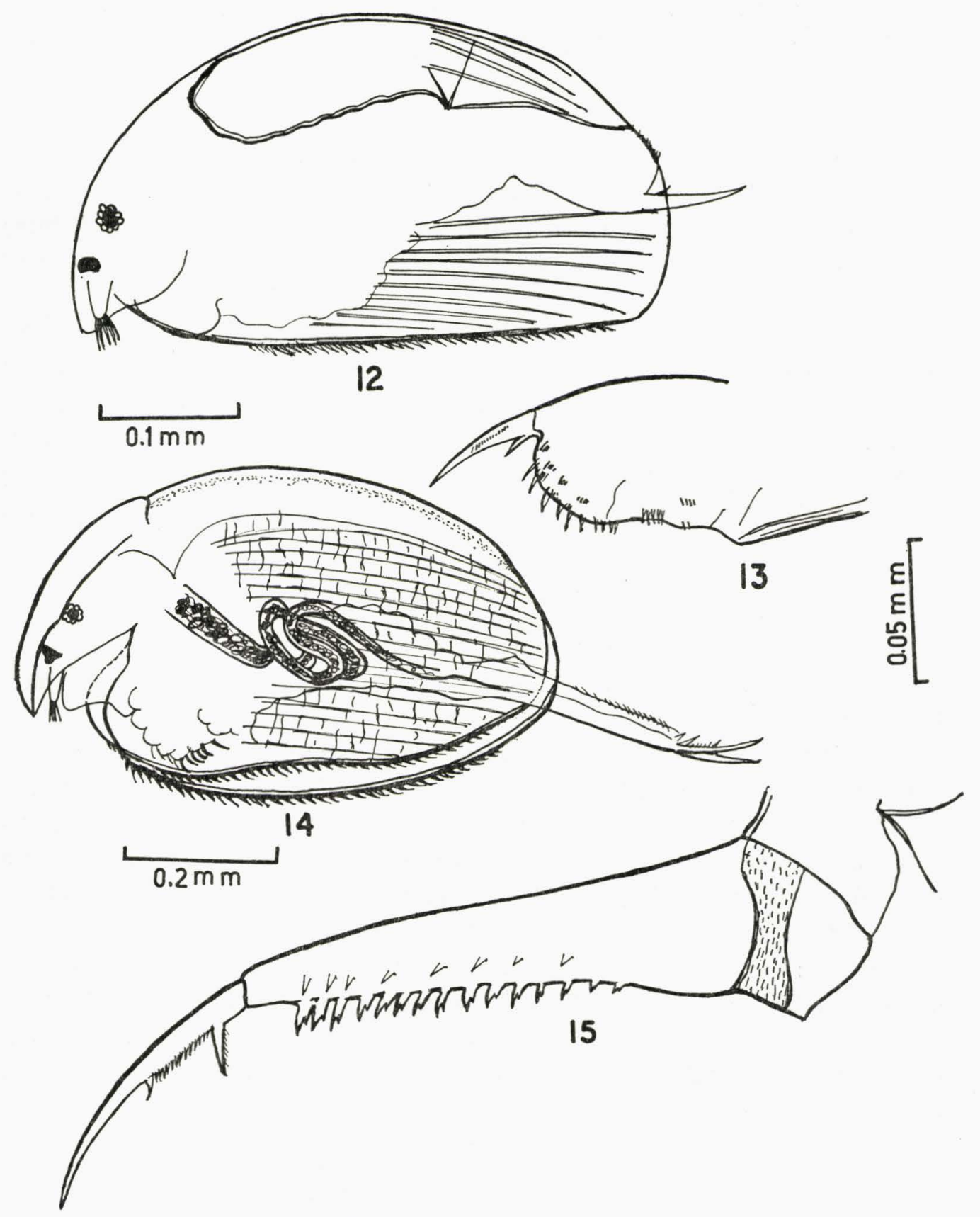

Biapertura sp. indet., female

Fig. 12. Entire animal from left side.

Fig. 13. Postabdomen.

Camptocercus kapuri sp. nov., female

Fig. 14. Entire from left side.

Fig. 15. Postabdomen. 
head shield with pointed posterior margin; main head pores two, with a narrow connection between them, lateral pores occur at the levels of anterior main pores; antennules almost reaching the apex of rostrum; antennal setae $0-0-3 / 1-1-3$; rostral plate with convex anterior margin; postabdomen not elongated, slightly widening distally, preanal corner projection making an angle of about $160^{\circ}$, ratio of $1: 16$ between distance from preanal corner to base of claws and maximum width of postabdomen, dorsal distal margin rounded having about ten unequal denticles, decreasing proximally; five or six small denticles occur in anal groove.

Male: Not found.

Measurements: (Slide Nos. $\mathrm{C}_{3} \mathrm{~F}_{1}$ and $\mathrm{C}_{3} \mathrm{~F}_{2}$ ): Length $=0.43-0.46 \mathrm{~mm}$, Height $=0.24$ $-0.25 \mathrm{~mm}$.

Colour: White, translucent.

Locality: Three female specimens of Biapertura sp. were found in a collection from a pond at village Lehra on (Ludhiana-Malerkotla road) on 8 February, 1974. The associated species which occured in abundance in the pond was Heliodiaptomus viduus GURNEY, a copepod.

Remarks: Presence of two main head pores undoubtedly justify the inclusion of the present species under the genus Biapertura. The species shows some similarities with the Biapertura affinis (LEYDIG, 1860), five subspecies of which have been recognized by Smirnov, 1971. The present form, however, differs from Biapertura affinis mainly in the details of postabdomen. The author prefers to retain the present species as indeterminate, because the paucity of material does not permit detailed examination.

\section{Camptocercus kapuri* sp. nov.}

(Figs. 14, 15)

Diagnosis: Carapace with faint transverse lines in addition to prominent longitudinal lines, eye and ocellus of equal size, keel of labrum large.

Female: Subovate, posterior end slightly narrower than anterior, compressed laterally; head and back with well developed crest; valves with rounded angles, ventral margin slightly concave in middle, inferaposteal angle smooth, longitudinal and faint transverse striations present; antennules short but olfactory setae projecting slightly beyond rostrum; labrum with a large triangular keel having a blunt apex; postabdomen very long, slender, narrow at distal end, with sharp preanal corner, postanal part with fourteen or fifteen marginal bident spines, lateral squamae also present; claw long with one basal spine, a series of small denticles terminating in a large one located about in middle of claw, distal part of claw spine smooth; eye and ocellus almost equal in size,

* This species is named in honour of Dr. V.C. KAPUR, Associate Professor of Zoology, Department of Zoology, Punjab Agricultural University, Ludhiana, India. 
intestine coiled.

Colour: Light yellow.

Male: Not found.

Measurements: Holotype (Slide No. ${\mathrm{C} 4 \mathrm{~F}_{1}}_{1}$ ) (우) Length $=0.69 \mathrm{~mm}$, Height $=0.4 \mathrm{~mm}$. Paratypes (Slide Nos. $\mathrm{C}_{4} \mathrm{~F}_{2}$ to $\mathrm{C}_{4} \mathrm{~F}_{5}$ ) (우 우) Length $=0.68-0.75 \mathrm{~mm}$, Height $=0.40-0.42 \mathrm{~mm}$.

Type locality: Five female spscimens of Camptocercus kapuri sp. nov. were found in a collection which was made on 12 January, 1974 from the slowly moving water of Budha Nala (Ludhiana) among the weeds.

Remarks: Camptocercus kapuri sp. nov. resembles Camptocercus australis Sars, 1896 in size and shape of the body, and especially in the rounded posteroventral corner of the valves. The postabdomen of Camptocercus kapuri sp. nov. also resembles somewhat that of Camptocercus rectirostris ScHODLER, 1862. However, it differs from the former in the structure of the postabdomen (in Camptocercus australis the postabdomen has a blunt preanal corner) and from the latter in the absence of denticles on the posteroventral corner of valves. Camptocercus kapuri sp. nov. differs from all the other known species of genus Camptocercus in the presence of faint transverse markings, in having eye and ocellus of almost equal size, and in shape of the keel of labrum.

Camptocercus australis SARS is the only other species of this genus known from India. This species was recorded by GuRney from CaIcutta in 1907.

\section{Leydigia ciliata GAUTHIER, 1939}

(Figs. 16-22)

Measurements: (우 우) (Slide Nos. $\mathrm{C}_{5} \mathrm{~F}_{1}$ to $\mathrm{C}_{5} \mathrm{~F}_{10}$ ) Length $=0.83-0.85 \mathrm{~mm}$, Height $=$ 0.46-0.47 mm. (令) (Slide Nos. $\mathrm{C}^{\mathrm{o}} \mathrm{M}_{1}$ to $\mathrm{C}_{5} \mathrm{M}_{4}$ ) Length $=0.52-0.56 \mathrm{~mm}$, Height $=0.31-$ $0.56 \mathrm{~mm}$.

Locality: Quite a good number of specimens (either sex) of Leydigia ciliata were collected from a pond of about one hectare and having a depth of half metre, located at village Machhali, $5 \mathrm{~km}$ from Chunni (Distt. Patiala) on 1 January, 1977. The water was slightly acidic ( $\mathrm{pH} 6.5)$.

Oxyurella singalensis (DADAY, 1898)

(Figs. 23-25)

Measurements: (Slide Nos. ${\mathrm{C} 6 \mathrm{~F}_{1}}_{1}$ to ${\mathrm{C} 6 \mathrm{~F}_{5}}_{5}$ ) Length $=0.54-0.67 \mathrm{~mm}$, Heightl $=0.35-$ $0.39 \mathrm{~mm}$.

Locality: Nine females of Oxyurella singalensis were found in the collection from the littoral region of river "Black Baeen" near Kanzli Bridge, Kapurthala on 7 May, 


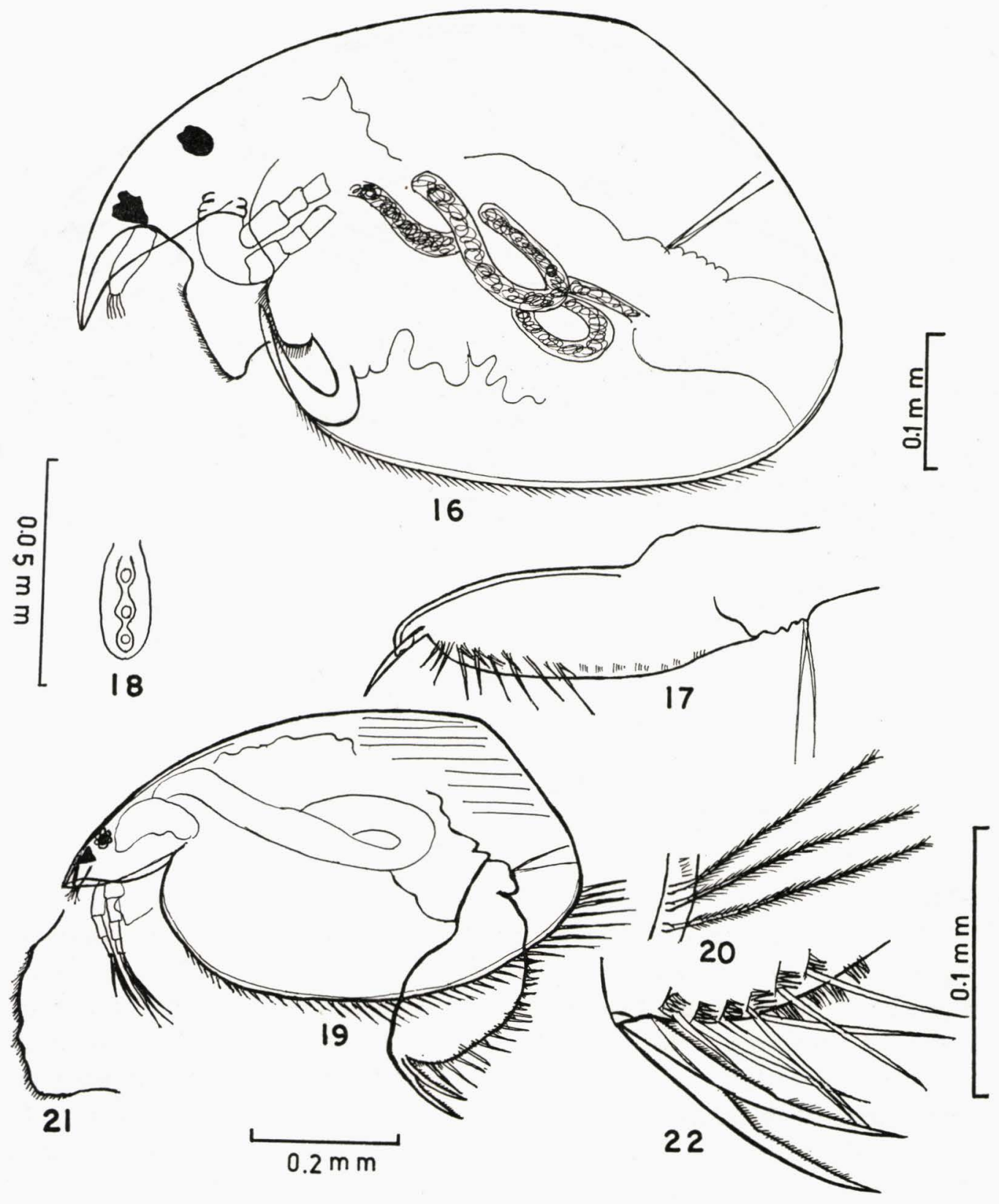

Leydigia citiata GAUTHIER

Fig. 16. Male, from left side.

Fig. 17. Male, postabdomen.

Fig. 18. Head pore.

Fig. 19. Female, from left side.

Fig. 20. Female, plumos bristles from posteroventral side of carapace.

Fig. 21. Female, keel of labrum.

Fig. 22. Female, part of dorsal margin of postabdomen. 


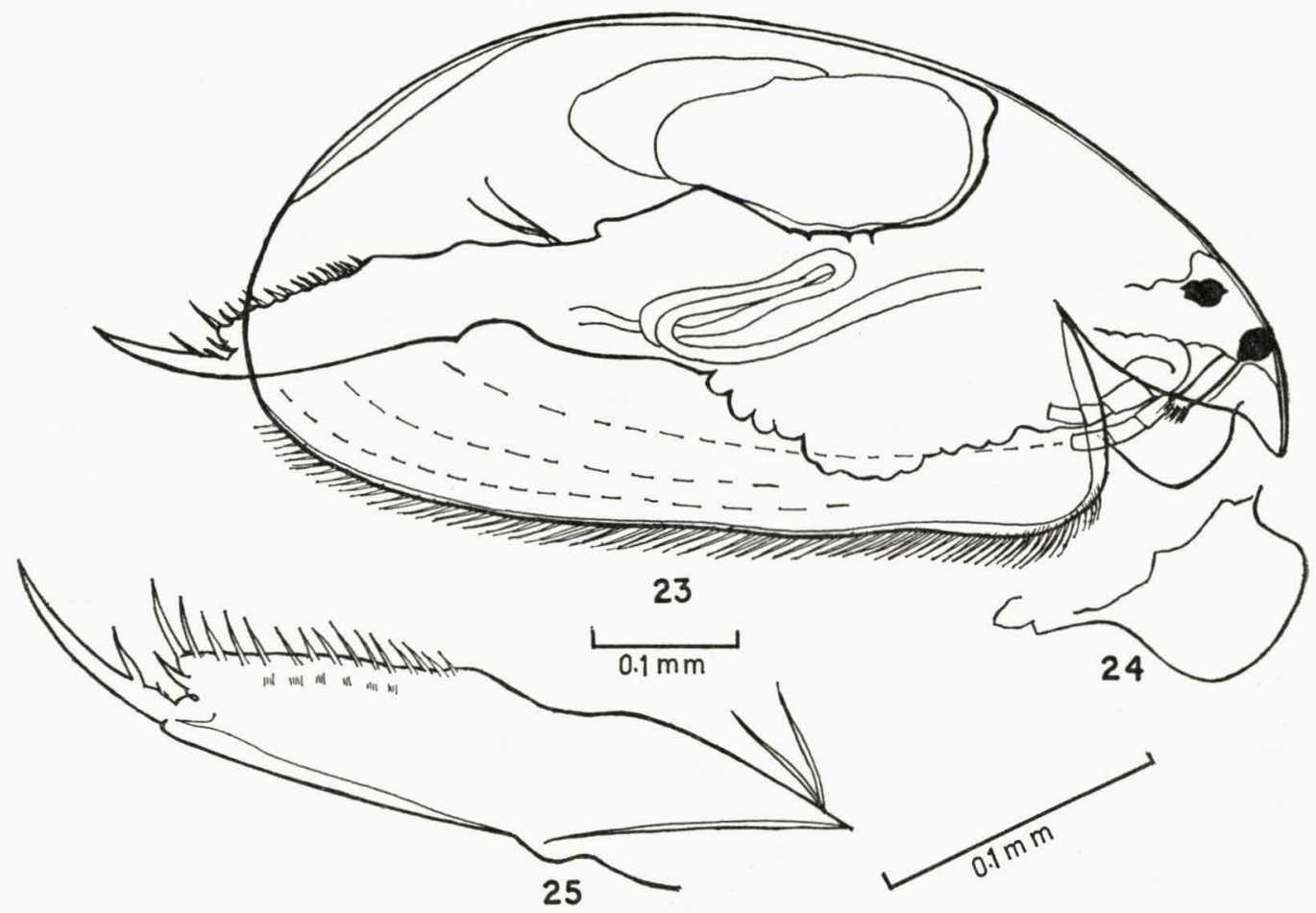

Oxyurella singalensis (DADAY), female

Fig. 23. Entire from right side

Fig. 24. Keel of labrum.

Fig. 25. Postabdomen.

1977.

Remarks: On comparing the present material with the figures and description of Oxyurella singalensis as given by SMIRNOV (1971) the following differences become apparent: (i) in the present from the labrum is without a pointed apex (Fig. 24); (ii) the ocellus is as large as the eye (Fig. 23), unlike Oxyurella singalensis in which the ocellus is half as large as large as the eye. In both above mentioned characters the present material resembles with Oxyurella wallaciana (HONRY, 1919). However, the body form and structural details of postabdomen in the present material are more similar to that of Oxyurella singalensis hence its identification. In the illustrations of REY and SAINT-JEAN (1969) from the material of Lake Chad, the labrum is not very pointed, and the ocellus is not so small as mentioned by SMIRnov (1971). Hence, the work of Rey and SAINT-JEAN (1969) support the identification of the present taxon as Oxyurella singalensis. 


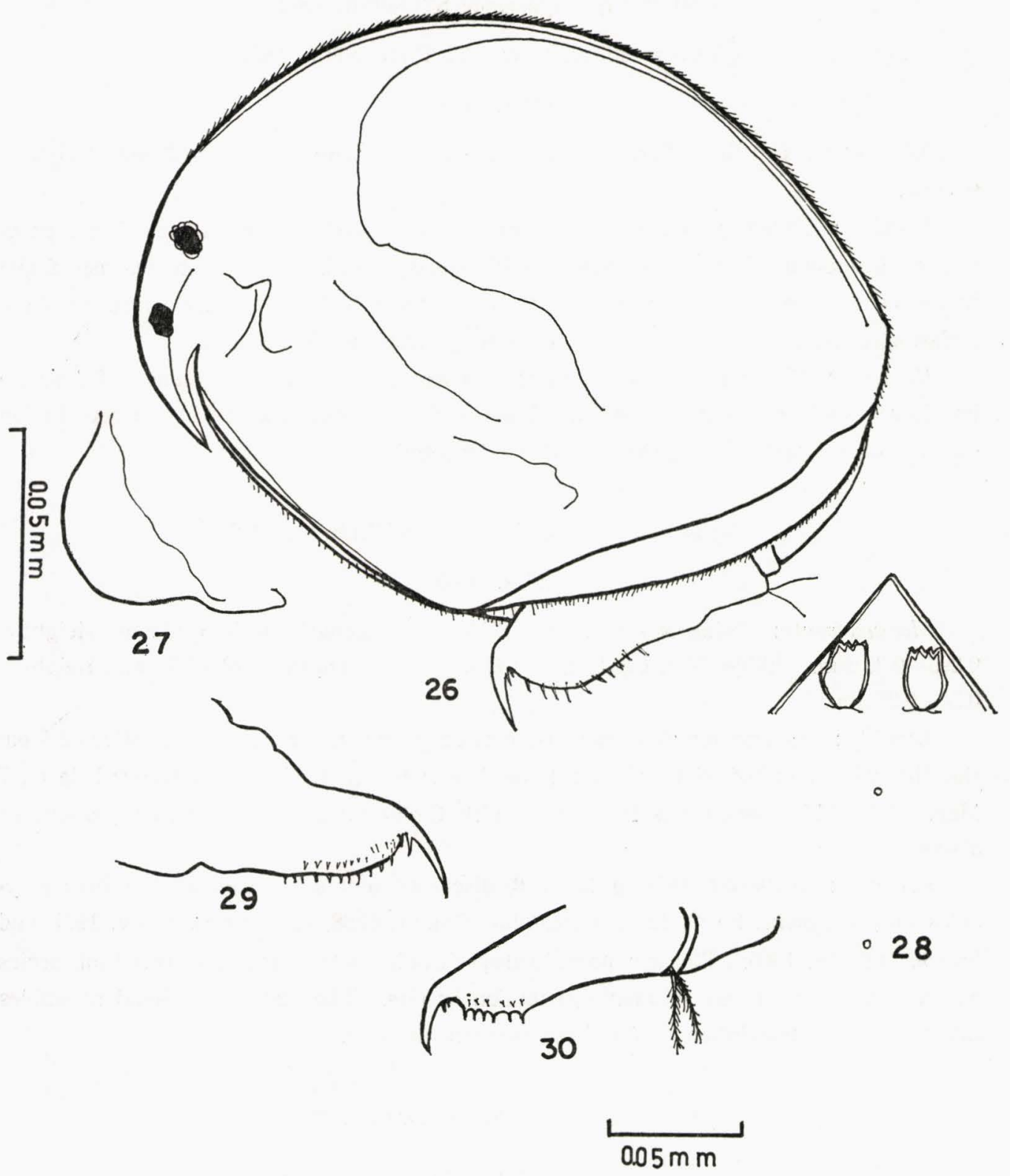

Chydorus sp. cf. C. ciliatus Poggenpol

Fig. 26. Female, from left side.

Fig. 27. Female, keel of rostrum.

Fig. 28. Female, rostrum and antennules from below; head pores.

Fig. 29. Female, postabdomen.

Fig. 30. Male, postabdomen. 
Subfamily Chydorinae StebBing, 1902

Chydorus sp. cf. C. ciliatus Poggenpol, 1874

(Figs. 26-30)

Measurements: (Slide Nos. $\mathrm{C}_{7} \mathrm{~F}_{1}$ to $\mathrm{C}_{7 \mathrm{~F}_{4}}$ ) (우 우) Length $=0.28-0.35 \mathrm{~mm}$, Height $=$ $0.3 \mathrm{~mm}$.

Locality: Seven specimens of this species were collected from a pond located at village Barmalipur (Doraha-Pial road) on 16 January, 1976. Other Entomostraca found in the pond were Macrothrix sp., Leydigia acanthocercoides (FISCHER), Pleuroxus sp., Heliodiaptomus viduus (GURNEY) and Mesocyclops hyalinus (REHBERG).

Remarks: The circular outline of the present taxon and the presence of hair on its dorsal surface bring it close to Chydorus ciliatus Poggenpol. Though reticulation on the ventral part of its valves could not be seen.

\section{Chydorus eurynotus SARS brehmi BISWAS, 1966}

(Figs. 31-33)

Measurements: (Slide Nos. ${\mathrm{C} 8 \mathrm{~F}_{1}}_{1}$ to $\mathrm{C}_{8} \mathrm{~F}_{5}$ ) (우 우) Length $=0.35-0.36 \mathrm{~mm}$, Height $=$ 0.295-0.30 mm. (Slide Nos. $\mathrm{C} 8 \mathrm{M}_{1}$ and $\mathrm{C} \mathrm{M}_{2}$ ) (令令) Length $=0.28-0.32 \mathrm{~mm}$, Height $=$ $0.26-0.30 \mathrm{~mm}$.

Locality: Several females (more than twenty) and three males were collected from the littoral region of river "Black Baeen" near Kanzli Bridge, near Kapurthala on 7 May, 1977. This species was found alongwith Oxyurella singalensis (DADAY) discussed above.

Remarks: SmiRnov, 1971 (p. 307-310) discussed four subspecies of Chvdorus eurynotus viz., eurynotus SARS, 1901, reticulatus DADAY, 1898, caelatus SMIRNov, 1971 and brehmi BIswAs, 1966. The last named subspecies differs from the other three subspecies as the valves of it are without reticulation or pits. The material at hand resembles fairly with the description of Chydorus euryrotus brehmi.

\section{Chydorus parvus parvus DADAY, 1898}

(Figs. 34-37)

Measurement: (Slide Nos. $\mathrm{C} \mathrm{F}_{1}$ to $\mathrm{C} \mathrm{F}_{10}$ ) (우 우) Length $=0.36-0.39 \mathrm{~mm}$, Height $=$ 0.295-0.34 mm.

Locality: Several (more than twenty) female specimens were present in a collection made from a stagnant water body located near Bus Stand, Anandpur on 16 November, 1975. The water was slightly alkaline ( $\mathrm{pH} 6.5)$.

Remarks: Chydorus parvus can be easily distinguished from all known species of 

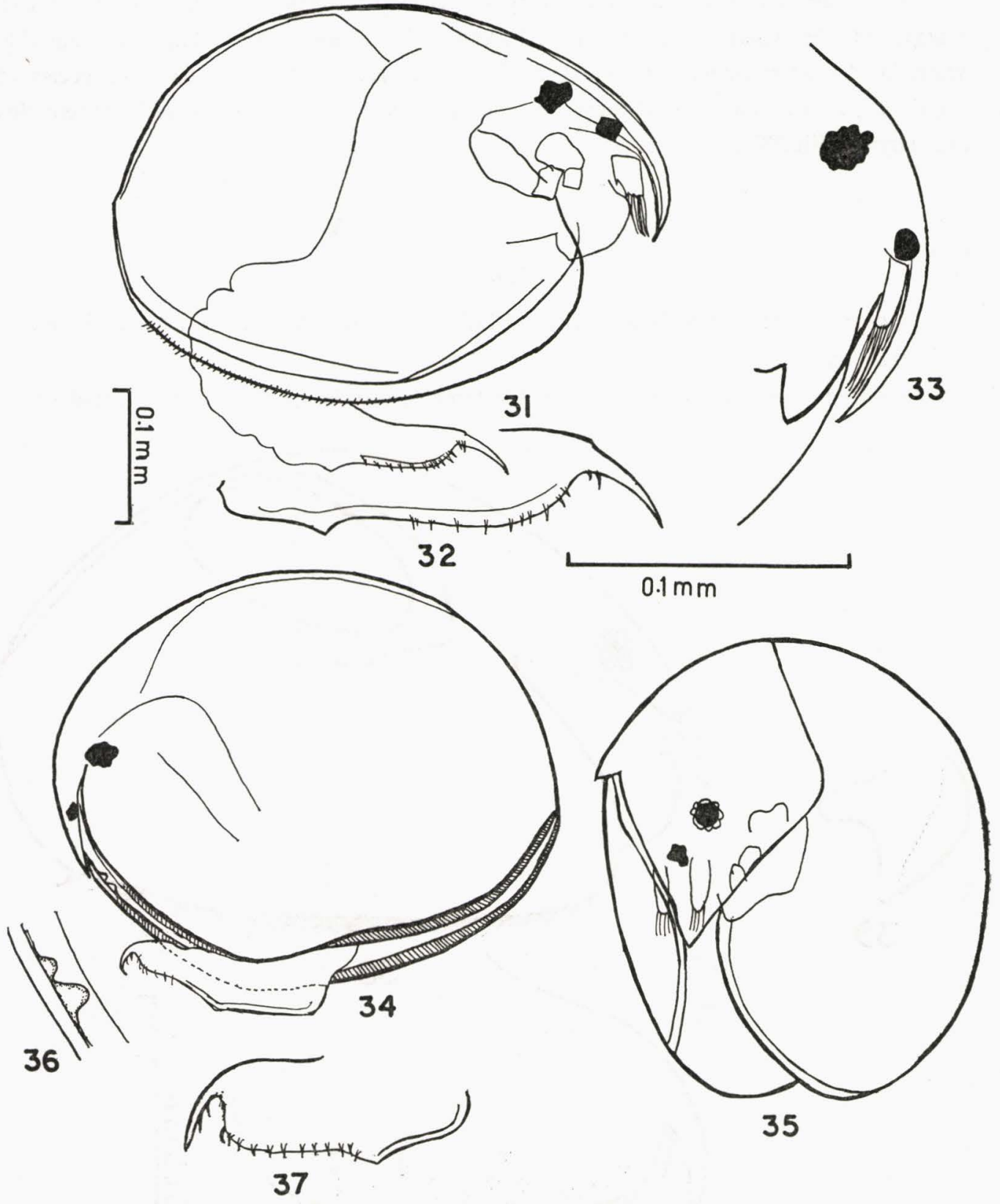

Chydorus eurynotus brehmi (BISWAs)

Fig. 31. Female, from right side.

Fig. 32. Female, postabdomen.

Fig. 33. Male, anterior end, lateral view. Chydorus parvus parvus Daday, female

Fig. 34. Entire, from left side.

Fig. 35. Entire, anterolateral view.

Fig. 36. Chitinous buttons at carapace margin

Fig. 37. Postabdomen. 
Chydorus LEACH, 1816 by the presence of tubercles or buttons on the inner anterior margin of the valves. According to FRYER (1957) these buttons exhibit considerable variability in arrangement and number. SMIRNOV (1971) recognises two subspecies of Chydorus parvus. The present form, however, is Chydorus parvus parvus as its antennules are narrow (Fig. 35).

Dunhevedia crassa KING, 1853

(Figs. 38-40)

Measurements: (Slide Nos. $\mathrm{C}_{11 \mathrm{~F}_{1}}$ to $\mathrm{C}_{11 \mathrm{~F}_{5}}$ ) (우 우) Length $=0.41-0.44 \mathrm{~mm}$, Height $=$ $0.27-0.29 \mathrm{~mm}$

Locality: Several (more than twenty) females of this species were collected on 11

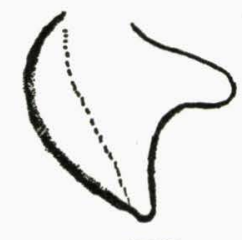

39
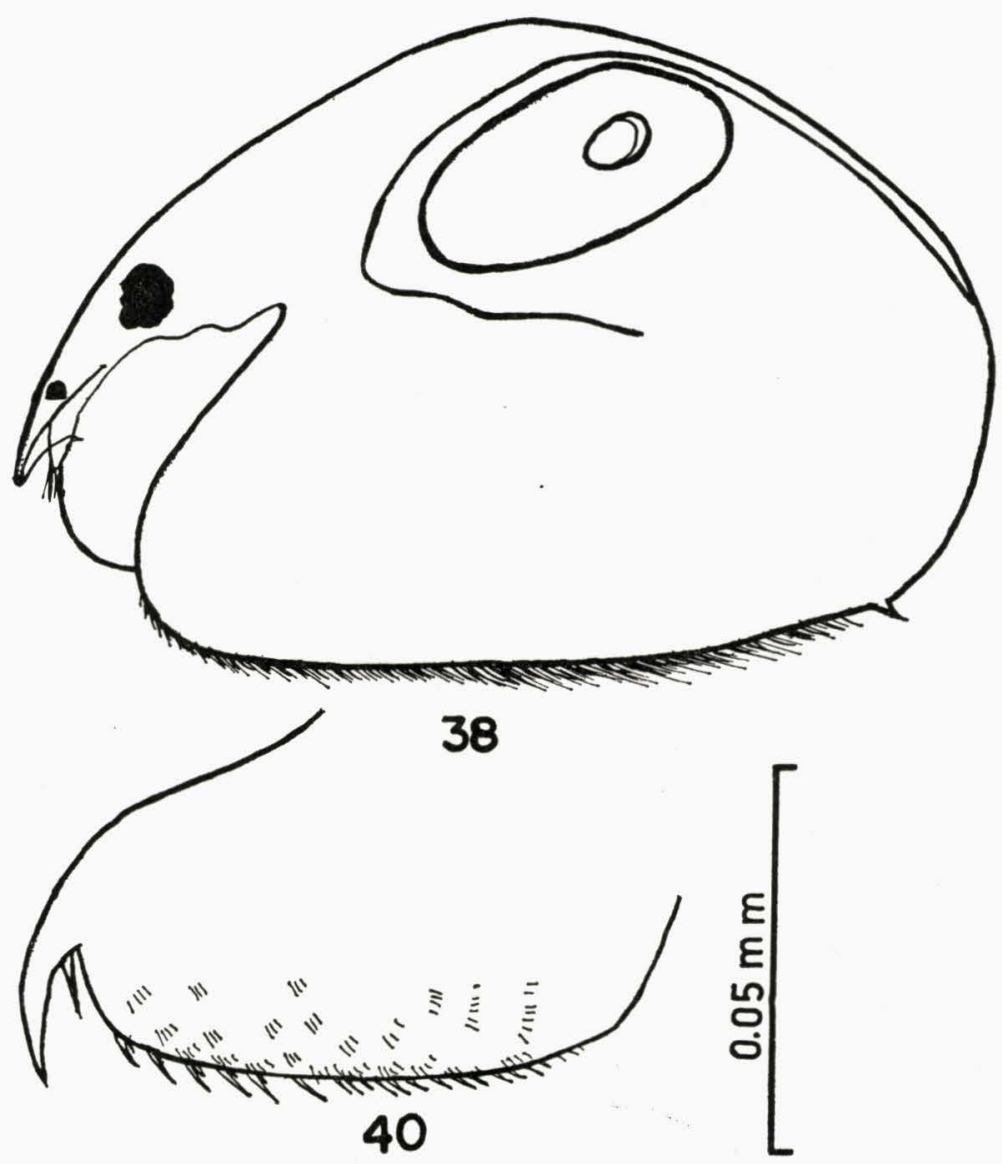

Dunhevedia crassa KING, female

Fig. 38. Entire, from left side.

Fig. 39. Keel of labrum.

Fig. 40. Postabdomen. 


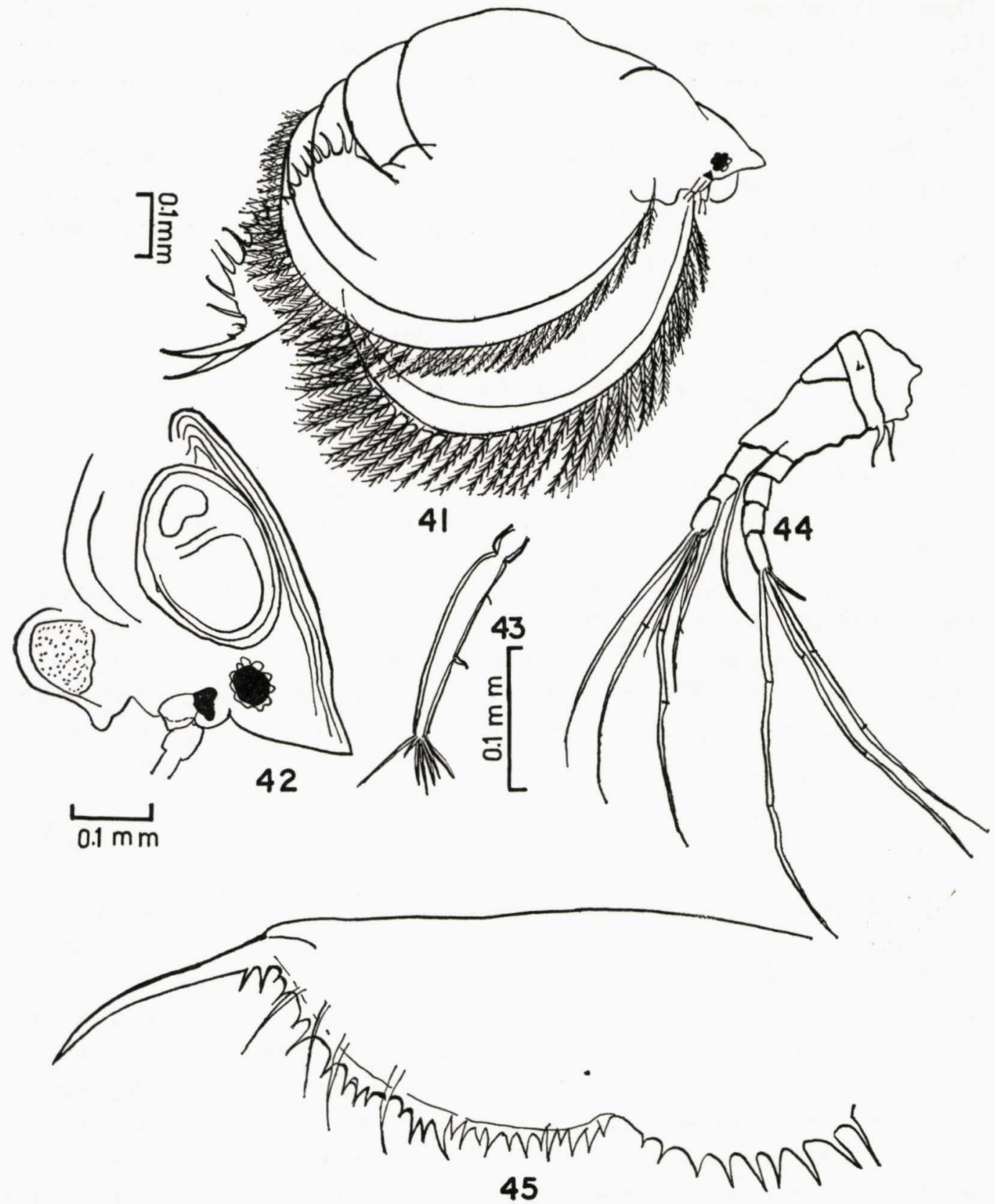

Ilyocryptus spinifer HERRICK, female

Fig. 41. Entire, from right side.

Fig. 42. Head, lateral view.

Fig. 43. Antennule.

Fig. 44. Antenna.

Fig. 45. Postabdomen. 
October, 1976 alongwith Alona pulchella KING, Simocephalus vetulus (ScHODLER) and Daphnia similis Claus from a water body near Model Town, Ludhiana having a water expanse of about three hundred meters and a depth of about forty $\mathrm{cm}$. This aquatic body was very rich in floating vegetation.

Remarks: The oval form having a denticle each at the posteroventral corner of the valves, the tumid carapace without a concavity in the middle when viewep dorsally (cf. D. podagra KING, 1853) and the absence of denticles on the plate of labrum justifies very well the identification of the present taxon as $D$. crassa.

\section{Family Macrothricidae}

Ilyocryptus spieifer HERRICK, 1884

(Figs. 41-45)

Measurements: (Slide No. $\mathrm{C}_{30 \mathrm{~F}_{1}}$ ) (ㅇ) Length $=0.78 \mathrm{~mm}$, Height $=0.62 \mathrm{~mm}$.

Locality: A single female specimen was found in a collection made from a small muddy ditch at village Churpur (Ludhiana) on 6 March, 1974.

Remarks: Like the other species of Ilyocryptus SARS, 1861. I. spinifer HERRICK has a ovate-subtriangular form. The carapace is thick and shows some growth lines as the old shells are not cast off during moulting but overlie the young in several layers. However, I. spinifer can easily be distinguished from the other species under this genus due to a large postabdomen having a fairly deep anal notch (Fig. 45).

\section{Ilyocryptus bhardwaji* sp. nov.}

(Figs. 46-49)

Diaghosis: Carapace reticulate, posterior margin of valves with characteristic notch, right and left valves (folds of carapace) slightly unequal in size; anterior surface of distal segment of antennule uneven.

Female: From triangular when viewed laterally, head short forming apex, covered with a broad thick and sclerotized headshield dorsally; dorsal margin or carapace arched, ventral margin circular, posterior margin with notch in the middle; ventral and posterior margins beset with long plumose immovable setae, anteroventral margin with twenty-one plumose spines, next twenty-one spines on ventral and posterior sides of valve margins with two unequal plumose spines each arising from a basal segment; valves reticulated; antennule long, freely movable, two jointed, basal joint small and oval, distal joint long having minute notches on anterior side, distal end bearing unequal olfactory setae; postabdomen very large, broad, compressed, with eight preanal marginal

\footnotetext{
* This species is named in honour of Mr. Bimal BhardwaJ of Phagwara in recognition to his
} help in collecting the material. 

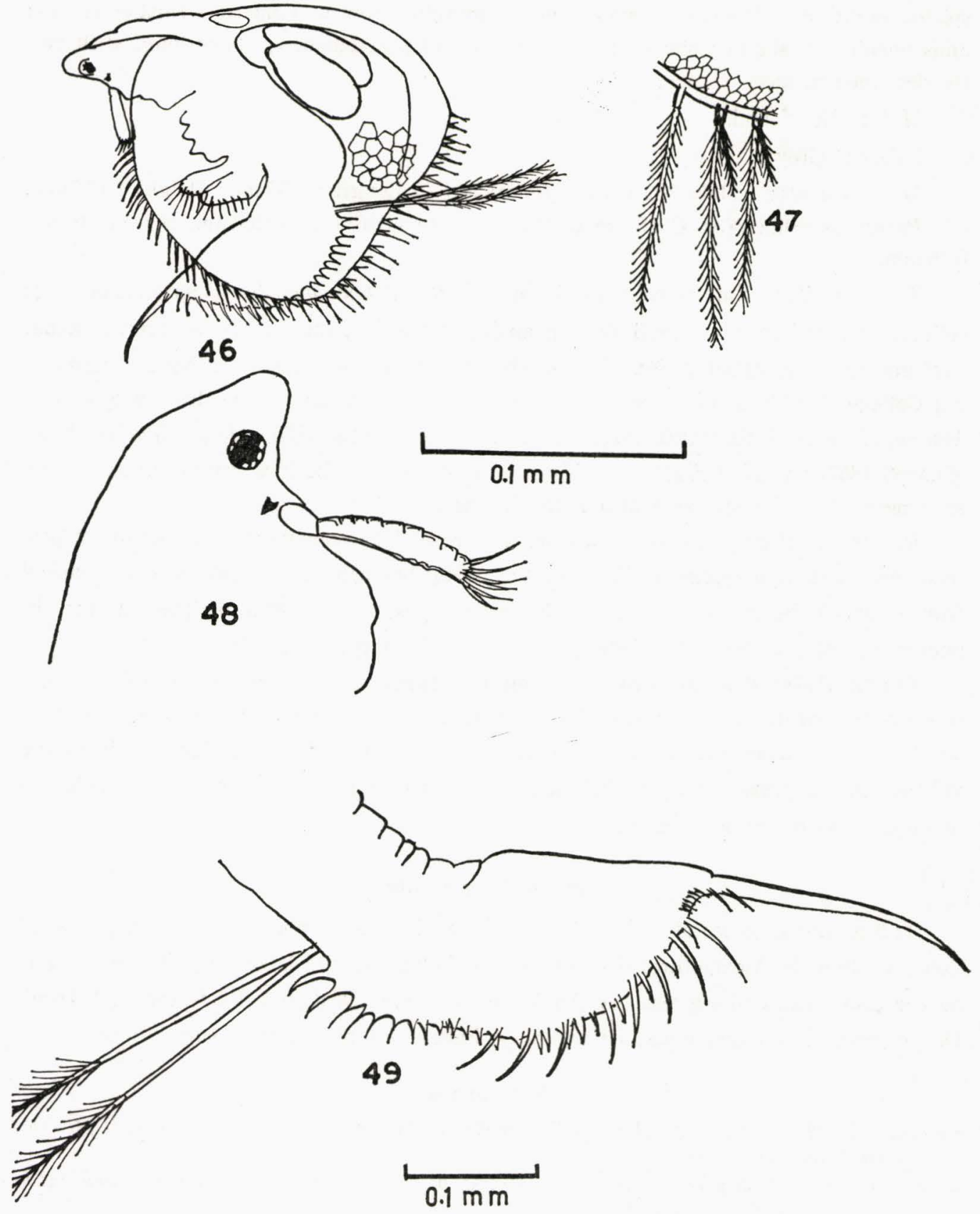

Ilvocryptus bhardwaji sp. nov., female

Fig. 46. Entire, from left side.

Fig. 47. Plumose bristle and branched bristles at mid carapace margin.

Fig. 48. Head and antennule, lateral view.

Fig. 49. Postabdomen. 
spines, eight lateral postanal spines, and a marginal row of numerous smaller spines; anus opening in shallow sinus on dorsal margin of postabdomen; claws long, with two slender unequal basal spines.

Male: Not found.

Colour: Grey

Measurements: (Slide No. $\mathrm{C}_{11 \mathrm{~F}_{1}}$ ) Holotype (우) Length $=0.55 \mathrm{~mm}$, Height $=0.45 \mathrm{~mm}$.

Paratypes (Slide Nos. $\mathrm{C} 1 \mathrm{~F}_{2}$ to $\mathrm{C} 1 \mathrm{~F}_{4}$ ) (우 우) Length $=0.43-0.55 \mathrm{~mm}$, Height $=0.36-$ $0.46 \mathrm{~mm}$.

Type locality: Nine female specimens of Ilyocryptus bhardwaji specimens were collected on 20 December, 1976 from a muddy roadside ditch having an area of about $4 \mathrm{~m}^{2}$ and depth of about $25 \mathrm{~cm}$. The ditch was located between Guru Nanak Engineering College, Ludhiana and village Gill. On the day of collection, the ditch was rich in Macrothrix goeldii RICHARD, 1897, Daphnia similis ClAus, 1876, Mesocyclops leùckarpi (Claus, 1857) and Heliodiaptomus viduus (Gurney, 1976). Besides Entomostraca, a few specimens of Hydra sp. were also found in the collection.

Remarks: Ilyocryptus bhardwaji sp. nov. resembles somewhat in structure of postabdomen with Ilyocryptus sordidus (LIEvIN, 1848) but can very easily be distinguished from it by (i) the presence of a notch on the posterior margin of the valves; (ii) unevenness of its antennules distally, and (iii) in having smaller size.

FRYER (1974) distinguished following two types of setae on the ventral and posteroventral margins of the valves of Ilyocryptus: (i) swimming setae, located ventrally on the valve margin and (ii) defensive spines occurring on the posterior margin of the valves. In the present species such setae consists of a basal segment from which two plumose setae of unequal lengths arise.

\section{Acknowledgements}

The author is grateful to Dr. S. S. GuRAYA, Professor and Head, Department of Zoology, Punjab Agricultural University, Ludhiana, for the laboratory facilities. The author also wishes to express his thanks to Dr. S.S. DHILlon, Professor and Head, Department of Zoology, Punjabi University, Patiala for his valuable suggestion.

\section{References}

Arora, G. L. 1931. Fauna of Lahore, 2 Entomostraca (Water-fleas) of Lahore. Bull. Dept. Zool. Punjab Univ., 1: 62-100.

BAIRD, W. 1860. Description of two new species of entomostracous Crustaceans from India. Proc. Zool. Soc. London, $00: 445$.

Battish, S. K. 1974. Occurrence and distribution of Cladocera in Punjab. Nat. Acad. Sci. India, 44th Annual Session, 00: 43 (Abstract).

Biswas, S. 1964. A new species of the Cladocera genus Latona Straus, 1820 from Rajasthan, India. Proc.Zool. Soc. Calcutta, 17: 149-152.

- 1966a. Five species of Daphnidae (Crustacea: Cladocera) from Simla Hills in India, with a new record of Along costata Sars from Kameng Division, NEFA. J. Zool. Soc. India, 
$16(1-2): 92-98$.

, 1966b. A new species of the Genus Chydorus Leach, 1843 (Cladocera: Chydoridae) from Rajasthan, India. Crustaceana, 11(2) : 113-114.

Brenm, V. 1936. Report of Cladocera. Yale North India Expedition. Mem. Conn. Acad. Sci., $10: 283-297$. 9-29.

1950. Contributions to the freshwater fauna of India. Part I. Proc. Ind. Mus., 48:

, 1952. Neue Entomostraken aus Indien. Anz. Ost. Akad. Wiss. math-naturwiss. K1, $5: 35-39$. 345.

, 1953. Indische Diaptomiden, Pseudodiaptomiden und Cladoceren. Ost. Zool. Z., 4:241-

, 1963. Einige bermerkungen zu vier indischen Entomostraken. Int. Rev. ges. Hydrobiol., $48: 159-162$.

BRooks, J.L. 1959. Cladocera. In: H. B. WARD and G.C. Whipple. Freshwater Biology. W. T. Edmondson (ed.). John Wiley and Sons Inc., New York, 00:587-656.

FRYER, G. 1974. Evolution and adaptive radiation in the Macrothricidae (Crustacea: Cladocera): A study in comparative functional morphology and ecology. Philosophical Transactions of the Royal Society of London. B. Biological Science, 269(898) : 137-272.

GuRNEY, R. 1906. On some freshwater Entomostraca in the collection of the Indian Museum, Calcutta. J. asiat. Soc. Bengal, $2(7): 263-281$.

- 1907. Further notes on Indian freshwater Entomostraca. Rec. Ind. Mus., 1: 21-23.

Michael, R.G. 1968. Studies of the Zooplankton of a tropical fish pond. Hydorobiologia, 32: $47-68$.

NASAR, S. A. K. 1977. The Zooplankton fauna of Bhagalpur (Bihar) II. Researches on Crustacea, No. 8. Carcinological Sociaty of Japan, 00:32-36.

NAYAR, C.K. G. 1971. Cladocera of Rajasthan. Hydrobiologia. 37: 509-519.

Petkovski, T.K. 1966. Eine neue Cladoceren-Gattung aus dem Westen Indiens Indialona ganapati n. gen. et n. sp. Fragmenta Balcanica musei Macedonici scientiarum naturalium, $522(132): 157-165$.

Sewell, R.B.S. 1934. A study on the fauna of the Salt Lakes, Calcutta. Rac. Ind. Mus., 36: 45-121.

Rey, J. and SAINT-jean 1969. Les Cladoceres (Crustaces Branchiopodes) du Tchad. Cah. O.R.S.T.O.M.; Ser. Hydrobiol., 3: 21-42.

Smirnov, N.N. 1971. Fauna of the U.S.S.R., Crustacea: Chydoridae (Translated from Russian in 1974). Academy of Sciences of the USSR-Zoological Institute, New Series n. 101, 1(2): 1-644.

TAndon, K. K. and NAyyar, M. 1971. Preliminary studies on the animal fauna of the garden pool. Res. Bull. (N.S.) Fanjab Uhiv., 22(1 and 2): 249.

VAsisht, H.S. and Singh, A. 1972. Crustacean faun of Sukhna Lake. Res. Bull. (N.S.) Panjab Univ., 23(1-11) : 115.

VAsisht, H.S. and S. K. Battish. 1974. The crustacean fauna of North India. Res. Bull. (N.S.) Panjab Univ., 25: 219-220.

インドのパンジャブ地方から 12 種の枝角亚目のミジンコが採集され記載した。その内 3 種は 新種である。ここに記録した種は下記の通りである。

Alona dhilloni sp. nov., A. pulchella KInG, Biapertura sp. indet., Camptocercus kapuri sp. nov., Ledigia ciliata GAUTHIER, Oxyurella singalensis (DADAY), Chidorus sp. cf. ciliatus PoggenPol, Ch. eurynotus brehmi BISwas, Ch. parvus parvus DADAY, Dunhevedia crassa KING, Ilyocryptus spinifer HERRICK, I. bhardwaji sp. nov. 